\title{
Slovene regional atlases: from SDLA-Ts to SDLA-SI
}

\author{
Rada Cossutta \\ Univerza na Primorskem, Znanstveno-raziskovalno središče Koper, \\ Garibaldijeva 1, SI-6000 Koper, rada.cossutta@zrs.upr.si
}

SCN III/1 [2010], 74-79

Prispevek se osredinja na prikaz dveh slovenskih dialektoloških regionalnih atlasov, ki bistveno dopolnjujeta furlanski atlas ASLEF: Slovenski dialektološki leksikalni atlas Tržaške pokrajine (SDLATs) (1987) za tržaški Kras in Slovenski dialektološki leksikalni atlas slovenske Istre (SDLA-SI) (2005-2006) za slovensko Istro. Njuna uresničitev pomeni nedvomno pridobitev za primorsko leksiko, ki je tu zapisana in kartografirana.

The paper focuses on the presentation of two Slovene regional dialectological atlases that significantly complement the Friulian atlas ASLEF: Slovene Dialectological Lexical Atlas of the Province of Trieste (SDLA-Ts) (1987) for the Trieste Karst and Slovene Dialectological Lexical Atlas of Slovene Istria (SDLA-SI) (2005-2006) for Slovene Istria. Their realisation undoubtedly represents an important achievement in the field of the dialectal lexis of Primorska, which documented and mapped in the mentioned two volumes.

Ključne besede: lingvistična geografija, slovenski regionalni atlasi, SDLA-Ts, SDLA-SI

Key words: linguistic geography, slovene regional atlases, SDLA-Ts, SDLA-SI

Twenty years have passed since my first contact with linguistic geography. I was a student at the time, working on my master's thesis and preparing for the exam in linguistic geography under the mentorship of Professor Logar, who introduced me to the principal stages of emergence and development of this field, as well as to Fran Ramovš' idea about a national linguistic atlas and his efforts to have such an atlas - 'an indispensable tool for dialect and language studies' - published. Logar dedicated a great part of his life to carrying out Ramovš' plan. After thoroughly explaining to me the advantages and disad- 
vantages of linguistic atlases, particularly national and multi-national ones, he switched his attention to regional atlases, which reveal - with greater accuracy, owing to the special adjusted questionnaires on which they are based - the most genuine aspect of the studied areas. Logar also stressed that the selection of research net points, dictated by the knowledge about linguistic situation and local problems, is in such cases more accurate. Finally, the research work itself, freed of the pressure from some more broadly designed project, which Logar himself had experienced, is carried out in a calmer and more thorough manner. After all these convincing findings Professor Logar brought forward an idea that he must have cultivated in his mind for a long time - that I start realising his plans myself, first in the Karst and then in Slovene Istria.

This is how my first engagement with linguistic geography began: from the first field studies involving awkward tape recorders that recorded the material on magnetic tape, to writing down the Slovene phonetic transcriptions with an Olivetti typewriter and producing the first maps, which I very conscientiously copied by hand from a geographical atlas of the Trieste outskirts. Despite the technology that is in today's terms utterly obsolete, the work paid off and in 1987 my first regional atlas of the province of Trieste SDLA-Ts saw the light of day. My research starting point was ten Slovene idioms evenly distributed over the entire Slovene environs of Trieste (Medja vas, Mavhinje, Samatorca, Križ, Prosek, Repen, Trebče, Gročana, Mačkolje, Korošci). My objective was to supplement the Friulian linguistic atlas (ASLEF), which encompasses the entire territory of the Venezia Giulia region where Friulian idioms can be found and thus the entire Trieste Romance territory that, in terms of dialect, used to be Friulian, but only incorporates two Slovene idioms (Zgonik and Žavlje), which cannot provide a complete picture of the ramifications of Slovene idioms in the Trieste environs. Therefore I decided to conduct a more detailed analysis of this area, based on the same Friulian questionnaire, but with added fieldwork in ten research net points in the Trieste outskirts.

The work was carried out it in various phases. First I thoroughly studied the ASLEF questionnaire, which is mainly lexical and quite demanding. Its content requires from the researcher and informant a great deal of knowledge concerning the material and spiritual culture of the studied area. The questions are very specific and concern the following areas: 1) natural phenomena and natural environment; 2) flora; 3) fauna; 4) hunting; 5) domestic animals, sheep farming, beekeeping; 6) parts of human body and diseases; 7) children's games and family; 8) social life; 9) house and household objects; 10) farm tools, crops, work in fields and stables; 11) garden plants, trees and related activities; 12) wine growing; 13) professions and housework; 14) cattle farming and dairy product processing; 15) forestry and wood processing. The original ASLEF questionnaire had 816 questions, but I omitted some which referred to activities that could not be found in the Province of Trieste and thus reduced their number to a total of 740. Then I proceeded with a careful selection of research net points. The location of some of the villages is really remarkable. Let me mention two that are situated on the outermost margin of the Trieste territory: 
Medja vas in the west and Gročana in the east. These two agrarian villages are accessed by a single road which ends in the village. Their inhabitants possess a certain individuality that is also reflected in the linguistic field and cannot be found in any other part of the Karst, as everywhere else the signs of gradual urbanisation and linguistic interference are already discernible.

The next issue was the selection of suitable informants. After I had completed the field study in my home town of Križ and the nearby Prosek, acquaintances and relatives put me in contact with people from the rest of the villages. A genuine chain of people formed, connecting village to village - people who weren't just willing to take part in the study, but also provided me with new contacts, which in several cases proved unique. I recorded their testimony on magnetic tape, replaying and transcribing it afterwards using the Slovene phonetic alphabet. In order to make my notes available to a broader circle of readers I added to the review of the vowel and consonant systems a table of the International Phonetic Alphabet. Based on the material gathered I divided the atlas into lists of words and 177 maps, which are mainly lexical, though occasionally the phonetic differentiation of the analysed dialectal territory in the Trieste outskirts can also be inferred from them. The maps are display maps, without visual cartographic symbols. Next to the numbers of the studied areas there is only the phonetic record of the answer to each question.

The result of the phonetic analysis of the mentioned dialectal material testifies that in the idioms of the Slovene Trieste territory dialectal phonetic phenomena of four Slovene dialects intertwine: the Karst, the Beneško-Briško, the Notranjsko and the Istrian dialects. The Karst dialectal element is the strongest, which is particularly manifest in the prevalence of the Karst vowel system. Typically Romanic influences can be traced in the loss of intonational and quantitative oppositions in stressed Slovene syllables, as well as in the markedly Romanic-type intonation on word and sentence level. Tine Logar, who wrote the introductory words to SDLA-Ts, found the gathered dialectological material to be most valuable to Slovene and Italian dialectologies, as it essentially supplemented ASLEF.

Upon the suggestion of Professor Crevatin and in constant cooperation with Professor Logar I carried on the work by studying the idioms of Slovene Istria, first from the viewpoint of agricultural and viticultural terminology, and publishing the gathered dialectal material in the monograph titled Poljedelsko in vinogradniško izrazje v slovenski Istri (Cossutta 2002) (Agricultural and Viticultural Terminology in Slovene Istria). From 1988 through 1990 I was helped in my fieldwork in Slovene Istria by three students of the College of Modern Languages for Interpreters and Translators of the University of Trieste (Vera Kukanja, Fedra Paclich and Marina Počkaj), who collected material to be used for their graduate theses and at the same time for the first draft of the dialectological atlas of Slovene Istria. Some of their chapters, which mainly dealt with flora and fauna, were expanded with new data that I collected in the following years on my own through fieldwork in Slovene Istria. Thus, I not only corrected the entire material, but also unified it and wrote it down again 
by means of Slovene phonetic transcription. In 1995, I completed the work and set out on what turned into an odyssey due to financial difficulties concerning the publication of the work and bureaucratic complications. In 2005, the Koper publishing house Annales proposed to publish the book. Thus, the first volume of the Slovene Dialectological Lexical Atlas of Slovene Istria (SDLA-SI) came out in 2005, followed by the second in 2006 .

The work is undoubtedly another achievement important to Slovene and Romance dialectology. It is constructed on the basis of the questionnaire for the Friulian atlas ASLEF and in this sense represents a continuation of SDLA-Ts, which was conducted in the Karst by using the same, albeit partly adapted questionnaire. The fieldwork was carried out according to the traditional dialectological method of tape recording and subsequent transcription with the Slovene phonetic alphabet. The atlas cites isolexes from 21 research points (Malija, Padna, Krkavče, Gažon, Šmarje, Koštabona, Pomjan, Boršt, Marezige, Trebeše, Belvedur, Pregara, Sočerga, Movraž, Osp, Dekani, Črni Kal, Potok, Kubed, Hrastovlje, Gračišče) evenly distributed over the territory of Slovene Istria. Professor Logar established this research network taking into account the fact that the territory represents a homogeneous whole, although the Koper-Marezige-Zazid dividing line separates it into two idioms: Rižansko and Šavrinsko.

The first volume of the SDLA-SI atlas contains original terminology from the following fields:

- Natural phenomena and natural environment (qq. 1-26); Flora (qq. 27-119); Fauna (qq. 120-213); Hunting (qq. 214-226); Domestic animals, sheep farming, beekeeping (qq. 227-263);

- Parts of human body and diseases (qq. 264-294); Children's games and family (qq. 295-318);

- Social life (qq. 319-341); House and household objects (qq. 342-386). The second volume deals with the following chapters:

- Farm tools, crops, work in fields and stables (qq. 387-534); Garden plants, trees and related activities (qq. 535-573); Wine growing (qq. 574-616); Professions and housework (qq. 617-667); Cattle farming and dairy product processing (qq. 668-714); Forestry and wood processing (qq. 715-740).

All dialectal material in the paper edition of the atlas is mapped, offering a dialectologist countless opportunities for drawing phonetic, morphological and semantic conclusions. The maps, which are entirely lexical, represent a valuable starting point for more thorough and detailed studies of the stratification of the idioms of Slovene Istria and their lexical differentiation. To appreciate the expressive richness and phonetic characteristics reflected in them it is enough to analyse a single map, for instance map 510 Well pulley, which serves as the starting point for the following findings: 
a) the differentiation with respect to the standard Slovene language is very clear: namely, Slovene Istria is not familiar with the standard Slovene expression for a pulley, which is škripec;

b) in the southern part of Slovene Istria two Romance loanwords coexist next to the Slovene expression 'kolo, acting as synonyms instead of necessary loanwords. One is paštteka, adopted through Istr. It. pasteca 'wooden pulley' (Rosamani 746) from the Ven. and Pad. pastèca 'metal single-wheel pulley' (Boerio 480), and the other is po'ranka, which derives from the Triest. and Istr. It. paranco / piranco 'pulley' (GDDT 471; Rosamani 734);

c) in Osp and Kubed there are two Romance loanwords in use as synonyms, pe'ranka / pe'rankå, and mal'nel / mal'nẹl, although the latter used to denote 'a wooden pole with two handles and a chain fastened to it', which corresponds to Triest. It. mulinel (GDDT 392) and Friul. mulignel or Istr. It. mulinel / molinel / muliniel 'grain mill' (Rosamani, 660, 639);

d) the variant pa'rankola, undoubtedly adopted from the It. parancola, is an isolated expression only used in Gračišče;

e) in terms of phonetics, we should mention the phenomenon of Romance expressions undergoing various phonetic adjustments to meet the phonetic norms of Istrian idioms (cf. pe'ranka, pa'ranka, pə'rånkå, pə'rankå); only the Dekani expression pi'ranka is adopted directly from the Istr. It. piranco. In this case only the phenomenon of metaplasm occurred;

f) the gender of the original Romance form of the masculine noun is only preserved in the Belvedur term pa'rank, while all other examples assert the phenomenon of metaplasm (pe'ranka, pa'ranka etc.).

The above-mentioned lexical and phonetic characteristics of the analysed map serve as additional evidence that the SDLA-SI atlas is a book opening new dimensions in Slovene and Romance dialectologies not only for word reconstruction, but also for the reconstruction of the linguistic landscape of the area under study.

\section{ABBREVIATIONS}

Ven. - Venetian; Istr. It. - Istrian-Italian; It. - Italian; Friul. - Friulian; cf. - compare; Pad. - Paduan; Triest. It. - Triestine-Italian 


\section{REFERENCES}

Rada COSSUTTA, 1987: Slovenski dialektološki leksikalni atlas Tržaške pokrajine (SDLA-Ts). Trieste: Slavica Tergestina, Università di Trieste.

- -, 2002: Poljedelsko in vinogradniško izrazje v slovenski Istri. Koper: Knjižnica Annales, 26.

--, 2005-2006: Slovenski dialektološki leksikalni atlas slovenske Istre (SDLA-SI). Koper: Knjižnica Annales Majora.

Enrico ROSAMANI, 1958, 1990 ( $1^{\text {st }}$ reprint): Vocabolario giuliano. Bologna, Trieste: Edizioni Lint.

GDDT- Mario DORIA - Claudio NOLIANI, 1987: Grande dizionario del dialetto triestino. Trieste: Edizioni "Il Meridiano".

\section{SLOVENSKI REGIONALNI ATLASI: OD SDLA-TS DO SDLA-SI}

Uresničitev regionalnih slovenskih atlasov, ki jih avtorica predstavlja v svojem referatu, se uokvirja v širši geolingvistični projekt, ki sta si ga zamislila dr. Tine Logar in dr. Franco Crevatin v prepričanju, ki ga je izrazil že Fran Ramovš, da so atlasi neobhodno potrebno sredstvo za študij dialektov in jezika. Avtorica Rada Cossutta je delo izvedla najprej s terenskim zbiranjem gradiva $\mathrm{v}$ desetih vaseh tržaške okolice po vprašalnici furlanskega atlasa ASLEF. Tako je leta 1987 nastal Slovenski dialektološki leksikalni atlas tržaške pokrajine ( $S D L A-T S$ ) kot prvi zamejski lingvistični atlas, ki ga je izdala Univerza v Trstu in ki še danes predstavlja dragoceno dialektološko gradivo za slovensko in italijansko dialektologijo. Avtorica prispevka je v naslednjih letih nadaljevala terensko delo v slovenski Istri z zbiranjem gradiva po isti vprašalnici v 21 vaseh slovenske Istre, ki je bilo nato zapisano s slovensko fonetično pisavo in je v letih 2005-2006 doživelo kartografirano izdajo v obliki atlasa Slovenski dialektološki leksikalni atlas Slovenske Istre (SDLA-SI I-II, Založba Annales Majora, Koper). Delo je po mnenju dr. Zorkove prvi organski in znanstveno utemeljeni poskus leksikalnega opisa istrskoslovenskih govorov ob upoštevanju trdno zasidrane slovenske terminologije ter romanskih in germanskih izposojenk, ki jih avtorica v prispevku predstavlja s primerom leksikalne karte. 